\title{
Fibich and Dvořák: The Hidden Friendship between Two "Enemies"
}

\author{
David R. Beveridge ${ }^{1}$
}

The "Dvořák battles" of the early twentieth century portrayed Dvořák and Fibich as opponents in the field of art. Dvořák's detractors, who long dominated Czech musicology, called him reactionary, whereas they championed Fibich as furthering the progressive ideals of Smetana. This dichotomy was over-simplified and exaggerated to say the least, but the image of opposition between Dvořák and Fibich fit well with patterns of perception already established during their lifetimes: many of their friends and supporters "on both sides of the fence" were inclined to see them as enemies-and not only in artistic ideals. The atmosphere is conveyed most vividly, no doubt with some exaggeration, by Dvořák's friend Josef Boleška in describing the attitude of the "Fibich camp" (here in my English translation from the Czech original, as with all quotations presented in this study): "[N]obody counted as a genuine and unbiased admirer of Fibich who did not absolutely condemn Dvořák." As concerns supporters of Dvořák, recently-published letters he received from several friends and relatives take a dim view of Fibich both artistically and personally, and would seem to lend strong support to the hypothesis of an unfriendly rivalry between the two composers. Perhaps most startling is a letter of February 1895 from Moric Anger, a conductor at Prague's National Theatre and a friend of Dvořák's since the days of their youth when they were roommates: "[T]o me you have always been the most sincere of all composers, and

\footnotetext{
For help of various kinds in preparing this study I thank Petr Dlabač, Jiří Kopecký, Vlasta Reittererová, and Ondřej Šupka.

2 Josef Boleška, "O Zdeňku Fibichovi. Několik vzpomínek na poslední desetiletí jeho života. (Pokračování.)" [About Zdeněk Fibich: Several Recollections of the Last Decade of His Life. (Continuation.)], Dalibor, 25 (1903), No. 39, p. 289. Ladislav Dolanský took issue with Boleška on this point. See his Hudební paměti [Musical Memoirs] (written in 1910), ed. by Zdeněk Nejedlý, $2^{\text {nd }}$ ed. (Prague, 1949), p. 215. However, three letters written to Fibich by his friends and published in Zdeněk Fibich. Sborník dokumenti̊ a studií [Zdeněk Fibich: A Collection of Documents and Studies], ed. Artuš Rektorys (Prague, 1952), Vol. 2 do suggest some resentment of Dvorák's success and a feeling that he was overrated to the detriment of Fibich. See the letter of 27 Feb. 1882 from V. V. Zelený (p. 489), of 3 April 1896 from William Ritter (p. 527), and of 16 April 1899 from Adolf Svoboda (p. 562).
} 
you haven't changed: you are as you were when we lived together [...]. Bendl is false. And Fibich, he is the most miserable musical monster existing in our country. For six weeks now we haven't been allowed to rehearse anything but [Fibich's opera] The Tempest, everything double cast-about 24 people-the whole operatic personnel." Later in this letter Anger refers to the appointment of Karel Bendl, on Dvoŕák's recommendation, to take his place as a teacher at the Prague conservatory while he was in America: "You can imagine how angry Fibich was with you because of the filling of your position at the conservatory. But now he's set up a bakery for operas-he's submitted one unfinished opera and the next one is already in the oven [...]." If Anger thought Dvorák would not be shocked by such venom, then we might suspect that Dvorák himself harboured less than the most kindly feelings toward Fibich. But let us not jump to conclusions.

No scholar has yet undertaken a thorough investigation of Dvořák's personal relations with Fibich. ${ }^{4}$ Symptomatic is the fact that the immensely voluminous Dvořák literature has almost totally ignored Zdeněk Nejedlý's 1911 publication of excerpts from conversations Dvořák had with Fibich as recorded by Otakar Hostinský-a publication quite valuable de-

\footnotetext{
All of the above-mentioned letters to Dvorák were published for the first time in 1999, in Antonín Dvorák: Correspondence and Documents, ed. Milan Kuna et al. (hereafter ADCD), Vol. 7 (Prague, 1999). Dates of letters and page numbers of the relevant passages are as follows:

Josefina Kounicová (sister-in-law): 2 Jan. 1893 (p. 15) and 7 Mar. 1894 (p. 182).

Karel Bendl: 8-9 Jan. 1893 (p. 23).
}

Alois Göbl: 30 Dec. 1894 (p. 324).

Moric Anger: [Feb. 1895] (p. 362-363).

Josef Boleška: 9 Mar. 1895 (p. 376).

Anna Dvořáková (daughter): 14 Mar. [1895] (p. 378).

The chronological concentration of these letters in 1893-1895 is striking, but may merely reflect the fact that this was the only extended period when Dvoŕák was absent from Bohemia: the frequency of all his known correspondence is much greater than average during this period, especially as concerns reports about musical happenings in Prague of which he had no need while he was there.

4 The enormous "Systematic Selective Bibliography" in Jarmil Burghauser's Antonín Dvoŕák: Thematic Catalogue ( $2^{\text {nd }}$, rev. and expanded ed., Prague, 1996) has a section for studies of Dvořák's relations with various individuals (p. 454-458). There are forty-nine of those individuals - almost incredibly not including Fibich. Otakar Šourek's four-volume monograph Život a dílo Antonína Dvoráka [The Life and Work of Antonín Dvořák] characterizes his relations with Fibich only very briefly, as follows (Vol. 4, $2^{\text {nd }}$ ed., Prague, 1957, p. 164): "If there was a certain tension between these two masters at times, it was probably evoked by intrigues of those around them more than personal bias; otherwise, as we see from the recollections of respectable contemporaries (Josef Zubatý, Ladislav Dolanský, and others), their relationship was characterized by mutual artistic understanding and also by contacts that were on the whole friendly." The most extensive discussion to date of personal relations between Fibich and Dvoŕák and their attitudes towards each other is by Jiři Kopecký in his Opery Zdeňka Fibicha z devadesátých let 19. století [The Operas of Zdeněk Fibich from the 1890s] (Olomouc, 2008), p. 73-76. Kopecký observes that "the two composers clearly respected each other" and that they "were apparently capable of communicating normally with each other, but were surrounded by a malignant atmosphere of intolerance". As we shall see, a wide spectrum of evidence allows us to confirm the tentative assertions of both Šourek and Kopecký, to flesh them out, and to express their positive aspects with less reservation. 
spite Nejedlý's probable intent to make Dvořák look foolish, and despite the highly selective nature of what Hostinský chose to record (perhaps guided in part by the same inclination). ${ }^{5}$ Dvoŕák's friend and biographer Boleslav Kalenský almost immediately cast serious doubt on the authenticity of Nejedlý's publication in a scathing review, ${ }^{6}$ and Dvořák scholars seem to have adopted a "hands off" policy toward this highly interesting document ever since. ${ }^{7}$ However, I am pleased to say that quite recently someone has finally located Hostinský's manuscript and published a complete transcription thereof that is more faithful to the original, namely our host at this conference Jiři Kopecký. ${ }^{8}$ His edition shows some of Kalenskýs suspicions to have been unfounded. One of the impressions conveyed by these conversational extracts-that Dvořák was naive, ignorant, and even stupid-deserves analysis in a separate study. Here I wish only to observe that they show quite vividly the nature of his personal relationship with Fibich: it was friendly, relaxed, and open.

Now that the dust of the "Dvoŕák battles" has settled, it is high time for us to stand back and take an objective look at the circumstances and nature of the personal relationship between these two composers based on all the available evidence.

Bohuslav Kalenský's long essay on Dvořák's youth and early adulthood reports plausibly that he first made the acquaintance of Fibich during musical soirées in the Prague home of Ludevít Procházka. ${ }^{9}$ This almost certainly occurred in 1871, not long after Fibich settled in Prague in May that year following several years spent mainly abroad. ${ }^{10}$ A public concert organized by Procházka on 10 December that year ${ }^{11}$ was the first of innumerable musical events over the course of three decades that we can specifically document as having included works by both Fibich and Dvořák, often (as in this case) in simultaneous premieres.

For Dvořák the concert on 10 December 1871 marked a major milestone in his career: apart from his own rendition of two short organ pieces in the graduation concert of the

5 “Z hovorů Ant. Dvořáka se Zd. Fibichem” [From A. D.'s Conversations with Z. D.], Smetana, 2 (1911), combined Nos. 3-4, p. 52-54. The conversations are dated from 1885 to 1889.

6 "Dvořákiana. Dvořák v líčení Fibichově a Hostinského" [Dvořákiana: Dvořák as Portrayed by Fibich and Hostinský], Dalibor, 34 (1911), No. 8, p. 63-64 and No. 9 (1912), p. 70-72.

7 Šourek does not mention it anywhere in his Život a dílo Antonína Dvořáka. The only reference to the article I have found in subsequent Dvořák literature is in Rudolf Pečman, Útok na Antonína Dvořáka [Attack on Antonín Dvořák] (Brno, 1992), p. 80-83.

8 In his compilation of documents titled Zdeněk Fibich. Stopy života a dila [Zdeněk Fibich: Footprints of His Life and Work] (Olomouc, 2009), p. 81-88.

9 Bohuslav (Schnabel-) Kalenský, "Antonín Dvořák. Jeho mládí, příhody a vývoj k usamostatnění” [Antonín Dvořák: His Youth, Experiences, and Development towards Independence], in: Antonín Dvorák. Sborník statí o jeho životě a díle [Antonín Dvořák: A Collection of Essays on His Life and Work] (Prague, 1912), p. 73.

10 Concerning Fibich's whereabouts see [Otakar Hostinský], "Fibich, Zdeněk", in: Ottův naučný slovník [Otto's Encyclopedia], Vol. 9 (Prague, 1895), p. 159, col. 2, and O. Hostinského Vzpomínky na Fibicha [Otakar Hostinský's Memories of Fibich] (Prague, 1909), p. 225.

1 See Hudební listy [Music Gazette], 2 (1871), Nos. 41-43, p. 347, 356, 362. 
Prague organ school in 1859 , this was the very first documentable performance of any of his compositions. Remarkable is the fact that Fibich, though nine years younger, had a wide lead over him in the development of his career at this time, with public performances of various works going back to $1865^{12}$ and also several publications to his credit ${ }^{13}$ another milestone that still remained in the future for Dvořák. ${ }^{14}$ For most of the coming decade Fibich remained a step ahead of Dvořák. His dramatic music, for instance, came to the stage sooner, with the premiere of his opera Bukovín at the Provisional Theatre on 16 April 1874 before Dvořák's Král a uhlír [King and Charcoal Burner] on 24 November that year. And he preceded Dvořák in attention given to his life, with a biographical sketch published already in June 1873 when he was only twenty-two years old; ${ }^{15}$ for Dvorák nothing of the kind appeared until more than six years later, when he was thirty-eight. ${ }^{16}$

In the early and mid-1870s Dvoŕák had more than ample reason to envy his younger colleague, who-by contrast with his own experience-had never struggled with poverty and had received a thorough education both musically and generally. However, we have not the slightest evidence that Dvořák actually felt such envy. Meanwhile Fibich, for his part, appears to have been kind to him. In April 1875, for example, Fibich wrote a quite glowing review of Dvořák's just-published String Quartet in a minor, B. $45 .{ }^{17}$ This despite the fact that here the tables were turned in terms of career advancement: none of Fibich's own chamber music composed up to that time had been published, even though some of it was probably superior to this quartet by Dvoŕák. ${ }^{18}$

From Fibich's arrival in Prague in 1871 until his death in October 1900 both composers had their principal residence in the Bohemian capital, their longest periods of absence being Fibich's year in Vilnius in 1873-187419 and Dvoŕák's two-and-a-half years in America in 1892-1895. Various evidence indicates that they saw each other in Prague fairly often.

12 See Vladimír Hudec, Zdeněk Fibich: Thematic Catalogue (Prague, 2001), Nos. 3, 4, 69, 72, 148.

13 See the works list in John Tyrrell and Judith A. Mabary, "Fibich, Zdeněk”, in: Grove Music Online. Oxford Music Online, http://www.oxfordmusiconline.com/subscriber/article/grove/music/09590 (accessed 11 July 2010). Publication dates of Fibich's works are given in parentheses.

14 With publication in 1873 of his six songs to texts from the Dvi̊r Králové Manuscript, B. 30.

15 [Václav Juda Novotný], “Zdeněk Fibich. Nástin kritický a životopisný” [Zdeněk Fibich: A Critical and Biographical Sketch], Dalibor, 1 (1873), No. 23, p. 186-189. The article is unsigned, but the contents for this volume of Dalibor specify Novotný as the author.

16 In Eduard Hanslick, "Concerte” [Concerts], Neue freie Presse, 23 Nov. 1879.

17 “Kritický oznamovatel” [Critical Informer], Dalibor, 3 (1875), No. 16, p. 131-132.

18 Further evidence of Fibich's support for Dvořák during this period is that in 1875-1876 he served on a jury of three that awarded Dvoř́k first prize in a composition competition for his String Quintet in G major, B. 49. See Dalibor, 3 (1875), No. 51, p. 412; Národní listy, 16 (1876), No. 78, př́loha p. [1]. And Adolf Čech, who conducted the premiere of Dvořák's opera Vanda on 17 April 1876, recalled his gratitude to Fibich who, as chorus director, was among those who supported the enterprise "with great self-sacrifice and uncommon diligence”: see Čech's untitled article in Dalibor, 23 (1901), combined Nos. 33-37, p. 267.

19 O. Hostinského Vzpominky na Fibicha (Prague, 1909), p. 225. 
Contacts between the two composers may have intensified after August 1875 when Fibich married Betty Hanušová, an alto who sang lead roles in the world premieres of all Dvořák's major vocal works given from 1874 to 1881, namely the operas Král a uhlír, Vanda, Šelma sedlák [The Cunning Peasant], and Tvrdé palice [The Stubborn Lovers] plus the Stabat mater. ${ }^{20}$ On 29 March 1879 Fibich himself performed as pianist in the premiere of one of Dvořák's lesser works, the Mazurek for violin and piano, B. 89. And Dvořák's own wife may have helped cement the connection: she performed the alto part in two Fibich duets on 20 March 1875,,$^{21}$ and sang in Prague's Russian Orthodox church during the period from October 1878 until April 1881 when Fibich was choirmaster there. ${ }^{22}$

Meanwhile the compositional outputs of Dvořák and Fibich progressed in parallel: each produced an abundance of works over a long period of time in almost all musical genres. However, the trajectory of Dvorák's reputation eventually showed a more dramatic rise: by the end of the 1870s he had overcome Fibich's early lead and gained recognition from most quarters as at least Fibich's equal. Then during the 1880s and 1890s his fame continued to grow by leaps and bounds, thanks mainly to successes abroad, and soon far outstripped that of his younger colleague. Thus by the time of Fibich's death in 1900 the potential for envy had switched: it was now Fibich whom one might expect to have been jealous. And even those who strongly prefer the music of Dvorák must admit the injustice of the tremendous gap in the degrees of recognition they achieved.

We need not be surprised that Fibich's devotees, in championing their hero, showed a tendency to downplay the genius of Dvořák. And it may well be that friends of Dvorák who learned of steps taken against him for the benefit of Fibich falsely attributed them to Fibich himself-hence the castigation of Fibich in the letters mentioned above. However, just as we have no record of Dvorák himself showing any envy of Fibich, the converse is also true. Indeed, I have found not a single derogatory word expressed by either composer against the other, except in jest and/or as a limited, friendly criticism of some particular aspect of their work. On the contrary, there is fairly copious evidence that their relationship was cordial and characterized by strong mutual admiration. ${ }^{23}$

20 Also in the premiere of the drastically-revised version of Král a uhliri in 1887 and the opening of a new production of Šelma sedlák in 1895. See Otakar Šourek, Život a dilo Antonína Dvoŕáka, Vol. 1, $3^{\text {rd }}$ ed. (Prague, 1954), p. 205, 208, 219, 274, 303 and Vol. 3, $2^{\text {nd }}$ ed. (Prague, 1956), p. 250.

${ }_{21} \quad$ See Hudební listy, 6 (1875), No. 13, p. 52 and Dalibor, 3 (1875), No. 15, p. 119.

22 O. Hostinského Vzpomínky na Fibicha (Prague, 1909), p. 226; Bohuslav Kalenský, "Antonín Dvořák. Jeho mládí, príhody a vývoj k usamostatnění", in: Antonín Dvorák. Sborník statí o jeho životě a díle (Prague, 1912), p. 93; Bohuš Frey, “U Dvořáků...”, Národní politika [National Politics], 47 (1929), No. 120, príloha p. 1, col. 2; letter from Karel Bendl to Dvořák of 21 Sept. 1890 in $A D C D$, Vol. 6 (Prague, 1997), p. 269.

23 Apart from sources directly quoted in the present study, see especially Hostinsky's above-mentioned excerpts from conversations between Fibich and Dvořák; see also Ladislav Dolanský's memoirs, p. 142, 200; Boleslav Kalenský, “Dvořákiana. Dvořák v líčení Fibichově a Hostinského”, Dalibor, 34 (1912), No. 9, p. 71; and Leoš Karel Žižka, Mistři a mistřičcové. Vzpomínky na české muzikanty let 1881-1891 [Masters and Lesser Masters: Memories of Czech Musicians, 1881-1891)], $2^{\text {nd }}$, expanded edition (Prague, 1947), p. 41-44. In 1887 Fibich published his Sonata in B flat major for piano four 
Given Dvořák's and Fibich's contrasting backgrounds and different inclinations, one might not expect them to have felt drawn to each other. But each was interested in the other's musical opinions, and they also had at least one shared interest far removed from their professions: both were passionate devotees of railways and locomotives. ${ }^{24}$

Highly interesting are recently-published documents concerning Dvořák's and Fibich's joint work, evidently quite harmonious, for the Czech Academy of Sciences, Literature, and Art from 1890 to 1898 , often as a team of two or with one other person, but also separately when they recommended each other's works for prizes. ${ }^{25}$ It was on Dvořák's recommendation that Fibich became a full member of the Academy in 1890, and a letter Dvorák wrote to Alois Göbl on 19 June that year suggests he was even prepared to defend Fibich against anticipated opposition in this matter: "Fibich, too, must be included among the full [members]. On that I stand firmly!"26

Preserved correspondence exchanged directly between the two composers is extremely sparse: there was apparently little need for it, since they often saw each other in person. We have only three items:

- Dvořák to Fibich, 21 Dec. 1888, birthday greetings ${ }^{27}$

- Fibich and Velebín Urbánek to Dvořák, [8 Sept. 1891], birthday greetings ${ }^{28}$

- Fibich to Dvořák, [17 Nov. 1898], congratulations on daughter's wedding. ${ }^{29}$

hands, Hud. 288 with a dedication "Milému přiteli Antonínu Dvořákovi” [To my dear friend Antonín Dvořák]. See Vladimír Hudec, Zdeněk Fibich: Thematic Catalogue (Prague, 2001), p. 340. (No work by Dvořák bears a dedication to Fibich.) Josef Bohuslav Foerster did allow that Fibich somewhat undervalued Dvorák's music-that he "overlooked the beauty of the content because it did not satisfy the formal aesthetic requirements that were sacred law to him at the time." See Foerster's "Vzpomínka" [Remembrance (of Fibich)], Dalibor, 32 (1910), combined Nos. 42-47 p. 344.

24 In Dvořák's case documented by innumerable reminiscences on the part of those who knew him. Concerning Fibich, see especially Richard Fibich (the composer's son), "O motýlech a vlacích" [About Butterflies and Trains], Dalibor, 32 (1910), combined Nos. 42-47, p. 320.

$25 A D C D$, Vol. 10 (Prague, 2004), p. 102-159. Dvořák received first prize in 1891 for his Requiem as recommended by Fibich and Karel Bendl; Fibich received first prize in 1892 for Hippodamie as recommended by Dvořák and Bendl, then in 1895 for Bouře (The Tempest) as recommended by Dvořák and Josef Foerster (senior).

This letter, in the holdings of the Antonín Dvořák Museum in Prague, acquisition number 128/99, remained unpublished until 2007, in Tereza Kibicová's “Antonín Dvořák nejbližšímu př́iteli II. Dosud nepublikovaná korespondence Antonína Dvořák adresovaná Aloisi Göblovi” [Antonín Dvořák to His Closest Friend II: Previously Unpublished Correspondence of Antonín Dvořák Addressed to Alois Göbl], Hudebni véda, 44 (2007), combined Nos. 3-4, p. 396, 398. In this publication the word rádnými (regular, proper, or in this case full [members]) is transcribed erroneously as zástupci (substitutes or representatives).

27 Published in Zdeněk Fibich. Sborník dokumentů a studií, ed. Artuš Rektorys (Prague, 1952), Vol. 2, p. 501 and in $A D C D$, Vol. 2 (1988), p. 345.

28 First publ. in $A D C D$, Vol. 6 (1997), p. 306.

$29 \quad$ First publ. in $A D C D$, Vol. 8 (2000), p. 99. 
All these communications are very brief, but they do reveal a high degree of familiarity including the familiar form of address-in Czech tykání-which Dvorák used with only a very few of the friends he met after the mid-1860s-not, for instance, with his truly intimate friend Alois Göbl, whom he probably met around the same time as Fibich. ${ }^{30}$ Worth quoting in full is the last of these letters: "Dear friend, Please accept my cordial, warmly-felt congratulations on the wedding of your daughter. Your sincere friend, Zdenko Fibich”. For fuller information on communications between Dvoŕák and Fibich we must rely primarily on reports from others about conversations they had-reports of which there are quite a few, albeit neglected in the secondary literature. Besides Hostinskýs above-mentioned extracts we have for example a very interesting recollection by Josef Zubatý:

Once there was a conversation among Dvořák, Bendl, and Fibich in the presence of myself, our [soon] deceased friend Zelený, and maybe others, about how tough it is for a Czech composer to get his music played abroad. Fibich said something like: "What about Dvořák? He's got it made: whatever he writes, they play it all." Dvořák replied: "Write something I like, and you'll see that it, too, will be played." The response was an explosion of laughter, and Fibich himself joined in sincerely. This event did not mar the friendly relations between the two masters at all. ${ }^{31}$

The element of joking-which we find also in several other reports on conversations between Dvoŕák and Fibich-is crucial. If indeed Fibich responded with sincere laughter, then he must have known that Dvořák did not mean his remark seriously, or at least not as a general condemnation of Fibich's music: we might imagine that shortly beforehand Dvořák had heard something in particular of Fibich's he did not like, and had expressed his opinion frankly. In any event Zubatý continues with confirmation that Dvoŕák did in fact appreciate Fibich's music: "On the other hand I also remember the pleasure this same Dvoŕák had not long thereafter from pieces for piano four hands [...] that this same Fibich brought to him in manuscript." (They were pieces composed in 1885 and 1886, including the Sonata in B flat major, Hud. 288 which Fibich dedicated to Dvořák.)

To close this study I should like to present a longer quotation, from an article on Dvorák by the music critic František Karel Hejda (1865-1919) published in a daily newspaper five years after Dvořák's death. ${ }^{32}$ It provides information on his relations with Fibich that

30 The familiar form of address also appears consistently in Hostinskýs above-mentioned extracts from conversations between the two.

31 Josef Zubatý: "Z upomínek na dra. Antonína Dvořáka” [From Memories of Dr. Antonín Dvořák], Hudební revue, 3 (1910), No. 1, p. 19.

32 "Antonín Dvořák v rodině a společnosti. Drobné vzpomínky k pátému výročí úmrtního dne mistrova" [Antonín Dvorák in His Family and in Society: Small Recollections for the Fifth Anniversary of the Master's Death], Národní politika, 1 May 1909, príloha, p. 2, col. 2. Given as the name of the author is "Notus", whom Otakar Šourek identifies as Hejda, plausibly judging by the article's content and by knowledge of Dvořák's relations with him. Šourek quotes two passages from the article (but not those 
to my knowledge has never been cited, including the mechanism by which the general perception of those relations has been distorted.

There has always been a surplus in our country of prejudices and erroneous opinions about Dvořák in general-which I could call by another name if I wished. For instance, unbelievably ridiculous and stupid legends have circulated about his personal and artistic relations with other outstanding Czech composers, especially Bendl and Fibich.

The master often said, "It seems to me that some people would like nothing better than to make me enemies with the whole world." And nothing made him so furious as the mentions found occasionally-even in daily newspapers-of some sort of "tension" or "anger" between him and the above-mentioned friends of his, to whom he always showed the most cordial friendship and every contact with whom was welcome to him. He especially appreciated and respected Zdeněk Fibich, speaking with admiration of his amazing intelligence and admirable diligence. When Fibich's magnum opus for piano, Moods, Impressions, and Reminiscences, was finished and published by F.A. Urbánek, Dvořák said: "If a foreign musical culture could boast of something like that, the composer would long since have been famous all over the world." And Fibich's operas evoked from him a characteristic statement: that few composers could show such a mighty rise in their progress from one opera to the next. Such was the "enmity" about which the most varied fables were tirelessly spread around Prague.

However, it must also be observed that nothing happened to support or justify these nonsensical legends on the other side either, that is on the side of Fibich. One morning Fibich, who had just submitted a new opera to the National Theatre, came as was his custom to join a group of artists gathered on Tyl Square in front of the National Theatre. During the conversation somebody said, with the clear intent of spoiling the master's mood:

"Dvořák has finished a new work and plans to submit it for performance within a few days; your opera will probably be put on the back burner." 33

Fibich replied calmly: "That is of very little consequence. But if Dvořák has finished his new opera, that is an event on which our musical world can only congratulate itself."

Despite the rancour among many supporters of Dvořák and Fibich, it is heartening to know that there were at least two figures who stood above it all, fully appreciating the

concerning Fibich) in his Život a dílo Antonína Dvořáka, Vol. 3, 2 $2^{\text {nd }}$ ed. (Prague, 1955), p. 258, note 11 and p. 282).

33 The only operas by Fibich and Dvořák to which this could apply, i.e. operas completed at about the same time, are Fibich's Pád Arkuna [The Fall of Arkona] (completed 25 Jan. 1899, premiered 9 Nov. 1900) and Dvořák's Čert a Káca [The Devil and Kate] (completed 27 Feb. 1899, premiered 23 Nov. 1899). 
talents and human qualities of both, and moreover that they were those figures whose opinion interests us the most: the composers themselves.

Fibich und Dvořák: Die verborgene Freundschaft zwischen zwei „Feinden“

\section{Zusammenfassung}

Die „Kämpfe um Dvořák“ zu Beginn des 20. Jahrhunderts haben Dvořák und Fibich als Rivalen dargestellt, was gut zu Wahrnehmungsmustern passt, die sich schon zu deren Lebzeiten eingebürgert hatten. Aber kein Wissenschaftler hat bis jetzt eine gründliche Untersuchung ihrer gegenseitigen, in Wahrheit harmonischen Beziehung angestellt.

Beide sind einander wahrscheinlich im Jahre 1871 zum ersten Mal begegnet, bei, oder kurz vor dem ersten der zahllosen Konzerte, von denen wir wissen, dass in ihnen Werke beider von ihnen, oft in gleichzeitigen Uraufführungen, auf dem Programm standen. Obwohl Fibich neun Jahre jünger als Dvořák war, hatte er einen Vorsprung in der Entwicklung seiner Karriere, und Dvořák hätte nur zu guten Grund gehabt, ihn zu beneiden - aber wir haben keinen Beweis dafür, dass er je diesbezügliche Neidgefühle gehabt hätte, und auch der junge Fibich scheint ihm gegenüber freundlich gesinnt gewesen zu sein. Als Erwachsene hatten beide Komponisten größtenteils Prag als Hauptwohnsitz und beide sind einander offensichtlich ziemlich oft begegnet. Ihre gegenseitigen Kontakte könnten sich nach der Verehelichung Fibichs mit Betty Hanušová verstärkt haben, da diese führende Partien in zahlreichen Uraufführungen von Dvořáks größeren Vokalwerken gesungen hat. Dvořáks Frau könnte noch dazu beigetragen haben, diese Verbindung noch auf die eine oder andere Weise zu festigen. Die kompositorische Produktion Dvořáks und Fibichs hat sich in gleichen Schritten entwickelt, aber Dvořáks Reputation ist auf spektakuläre Weise angestiegen, sodass sich die möglichen Neidgefühle theoretisch auf die Seite Fibichs verlagern hätten können. Aber auch er scheint gegen Eifersucht immun gewesen zu sein. Alles deutet vielmehr darauf hin, dass ihre gegenseitige Beziehung freundlich und voll gegenseitiger Hochschätzung geblieben ist. Aufschlussreich sind in dieser Hinsicht Dokumente über ihre gemeinsame Arbeit im Rahmen der Tschechischen Akademie der Wissenschaften, Literatur und Kunst, ebenso wie Berichte über ihre Gespräche miteinander und Aussagen des einen über den anderen. Einer dieser Berichte gibt Aufschluss über die Art und Weise, wie die Wahrnehmungen ihrer gegenseitigen Beziehung verzerrt worden sind.

Übersetzt von Vlasta Reittererová 


\title{
Fibich a Dvořák: skryté prrátelství mezi dvěma „nepřáteli““
}

\begin{abstract}
Shrnutí
„Boje o Dvořáka“ ze začátku 20. století ukázaly Dvořáka a Fibicha jako rivaly, což dobře zapadlo do recepčních stereotypů, které se vytvořily již za jejich života. Ale zatím žádný badatel nepodrobil důkladnému výzkumu jejich osobní vztah, který byl ve skutečnosti harmonický. Skladatelé se pravděpodobně poprvé setkali v roce 1871 při nebo krátce před prvním z nesčetných koncertů, na jejichž programech se často zároveň ocitly premiéry děl obou autorů. Ačkoliv byl Fibich o devět let mladší než Dvořák, začal svou kariéru dříve, a Dvořák měl víc než dostatečný důvod k nenávisti, ale nemáme žádný důkaz nějakého odtažitého chování, a také jednání mladého Fibicha se jeví jako přátelské. Oba skladatelé se usadili v Praze a zřejmě se často vídávali. Jejich kontakty mohly zesílit po svatbě Fibicha s Betty Fibichovou, jež zpívala stěžejní role při mnoha světových premiérách Dvořákových velkých vokálních děl. Tento vztah mohla upevnit různými způsoby ještě Dvořákova manželka. Dvořákova a Fibichova skladatelská produkce se vyvíjela současně, ale Dvořákův věhlas nezastavitelně rostl, což případně mohlo vzbudit nenávist, ovšem také Fibich se zdá být imunní vůči žárlivosti. Vše nasvědčuje tomu, že jejich vztah zůstal srdečný a plný vzájemného uznání. Důležité jsou pro nás jak dokumenty, které se týkají jejich společné práce pro Českou akademii pro vědy, slovesnost a umění, tak záznamy jejich rozhovorů a prohlášení, která o sobě vzájemně pronesli. Jedna z těchto zpráv obsahuje vysvětlení způsobu, jakým došlo ke zkreslení pohledu na jejich vztah.
\end{abstract}

\section{Keywords}

Antonín Dvořák; Zdeněk Fibich; Dvořák battles. 